これは常にワンテンポ遅れた循環補整を意味する。そ こでわれわれは最も重要な血行動態パラメータである 血圧を一定に保つベくバルーンパンピングが制御され る方式を考案した.

〔方法】 圧トランスデューサから得られる動脈圧波 形に対し，電気的に upper limit および lower limit を設け，動脈圧が upper limitに達した場合には puming off とし, 動脈圧が lower limit を下回った 場合には pumping on とすることにより動脈圧を upper, lower 両 limit 間に概略一定に保方得る. ま た動脈圧が上昇して pumping off となり weaning 状 態となった場合には血栓予防の面から 1 分間に数回 pumping on とした.

〔方法】 雑種成犬にて出血によるショック, 冠動脈 結禁汇よる心筋梗塞などを作成し， upper, lower 両 リミットはさまざまに設定してバルーンの作動状態を 観察した.

〔結果】血圧の上下変動に応じて pumping 回数は 增減し概略，既定の目標血圧を維持し得た。 upper， lower 両リミットの閒隔を広げると pumping 回数が 減少し血圧の変動がやや著しく, 両リミットの間隔 を狭めると, pumping 回数が増加し，血圧の変動は 少なかった，昇圧扸により血圧上昇させると自動的に weaning できた.

[結論]血圧を一定幅に保つように pumping 回数 を制御するわれわれの方法は踣床的には十分実用的々 考えられるが，今後，左房圧，CVP，C.O，その他の パラメータも使用した・よりキメの細かい，洗練され た自動制御法を追求したい。

\section{3. 血液灌流用シールレスポンプ}

\section{北海道大 応電研 MTR \\ 田中志信 山越憲一 神谷 暸 \\ 北海道大 工学部流体工学第 1 講座 \\ 佐藤孝之 木谷勝 㸡テルモ $\mathrm{ME}$ 開発課 \\ 田島秀朗横山能周 \\ 日下部正宏}

近年重症心不全等の外科的治療における体外循環あ るいは心贜補助循環の有效性が評価され，これに伴い 小型・簡易構造で操作が簡便な血液ポンプの開発が望 まれている。一方，現在このような目的に用いられて いる血液ポンプのほとんどがローラポンプあるいは圧
縮空気駆動のダイアフラムポンプで，いずれも大型の ポンプ駆動部を必要とし高価でもある. 遠心式の血液 ポンプも数種市販されているが，羽根車回転軸シール 部の耐久性に問題があるうえ，ポンプヘッドの構造も 複雑で，駆動装置を含め非常に高価なものとなってい る.そこで演者らはこの上うな現状を鑑みポンプ駆動 部にブラシレス DC サーボモータの駆動方式を忘用 し，小型・簡易構造の血液灌流用シールレスポンプの 試作を行った。

試作ポンプはいわゆる非容積式ポンプの一種で，羽 根車自体仪駆動用およびスラータ用の円筒状マグネッ 卜を内臓し，ケーシング外部の歌動コイルによりこれ を直接回転させるため, 軸受および軸封機構のまった く無いシールレス構造となっている.

ポンプ試作に当たり，ポンプ特性を大きく左右する 羽根形状を変化させたものを数種用意し, in vitro 試 験下で性能比較を行い最適形状を決定した。 また試作 ポンプを，雑種成犬を用いた in vivo 試験に適用し性 能圾験を行ったところ, 本ポンプの有效性が確認され た.

\section{4. 補助人工心臓用ポリウレタン製人工弁 の試作}

国立泪環器病センター研究所
人工藏器部
野田裕幸
中谷武嗣 津光生
中羲之
中 隆 岩田博夫
松田武久
阿久津哲造

[目的] 補助人工心臟 $(V A D)$ 用として $1 \sim 3$ 力月 程度の使用に耐え得るポリウレタン製人工弁 (PU 弁) を試作する。

〔デザイン，材料および製作〕形状は三尖弁とし， 完成時, 成人 VAD 用で市販される他の弁の $25 \mathrm{~mm}$ に相当する. 東洋紡社製 segmented polyether-polyurethane TM シリーズを用い， dipping 法による一 体成型を行う．ステントの補強は, 現在ステンレスワ イヤーおよび塩化ビニルによるものの 2 種を検討して いる. 前者は比較的固く, 後者は flexible である.

[評価方法および結果〕陚作したPU 弁について, 従来当研究室で行ってきた水力学的特性試験を行い, 泪販の同等の人工弁と比較検討する.

1）定常流抵抗試験：PU 弁は，その厚みが各リー 